\title{
Physico-Chemical Characterisation of Aerosol Particles at Canopy Level in Urban Zone
}

\author{
S. Despiau \\ LSEET-LEPI / UMR 6017/Université du Sud Toulon-Var
}

France

\section{Introduction}

For many years, national and/or international research programs devoted to understand the effects of aerosol particles on health (COST action 633, ..) and/or climate (ACE experiments, INDOEX, TARFOX, NAMBLEX ...) have been carried out in various regions of the world and at various scale of time and space and more and more papers are published in connection with these two effects, health (Dockery et al., 1993; Dockery and Pope, 1994; Oberdörster, 2000; Pekanen et al., 1997 ; Pope and Dockery, 1999; Pope et al., 2002; Wichmann and Peters, 2000; ...) and climate (Charlson et al., 1992; Jacobson, M.Z., 2001; Kaufman et al., 2002; Penner et al., 2004; ...).

These effects are mainly the consequence of the physico-chemical characteristics of the aerosol particles that depend first on the mode (natural, anthropogenic, primary, secondary) and place (urban, industrial, rural, marine, coastal zones ...) of production. They depend also on their transformation during transport, which is mainly depending on the meteorological conditions prevailing in the region where the experiments are carried out, the occurrence of possible and specific sources and sinks all along the pathway of the air mass. Whatever the scale considered, a global watch of these effects and their possible future changes requires the availability of adequately emission inventories (François et al., 2005) and the use of numerical models which improvement assumes accurate comparisons with experimental data (Builtjes et al., 2003, Cousin et al., 2005).

The two main objectives of the regional ESCOMPTE experimental campaign (Cros et al., 2004) which took place in the south of France in the "Fos-Berre-Marseille" region in JuneJuly 2001, were to study the numerous photochemical pollution events that occur in that region and to produce a relevant set of data for testing and evaluating regional pollution models. Among the various data sets recorded during the campaign, the one concerning the aerosol particles resulted from the measurements realised in 7 sites representative of industrial, urban, suburban and rural areas (Cachier et al., 2005). It is well known that urban zones are a strong and complex source of aerosol particles but an "urban source" is difficult to characterize precisely. In order to try to provide data characterising better one urban zone, it was decided to realise the measurements at a height representative of a mean urban "canopy level". The measurements were then carried out on the roof of a public building localized in Marseille downtown. 
The main results obtained during the campaign are presented here and are considered with respect to two main questions:

Have the particles particular physico-chemical characteristics at canopy level and are these characteristics useful for modelling purposes or for emission inventories validation?

Are IOP situations (described hereafter) leading to a specific signature in terms of particle characteristics?

\section{Experimental campaign and methodology}

The experimental zone of the ESCOMPTE program covered an area of 120x120 km centred on the "Marseille-Berre" region, including an important coastal zone (Fig. 1).

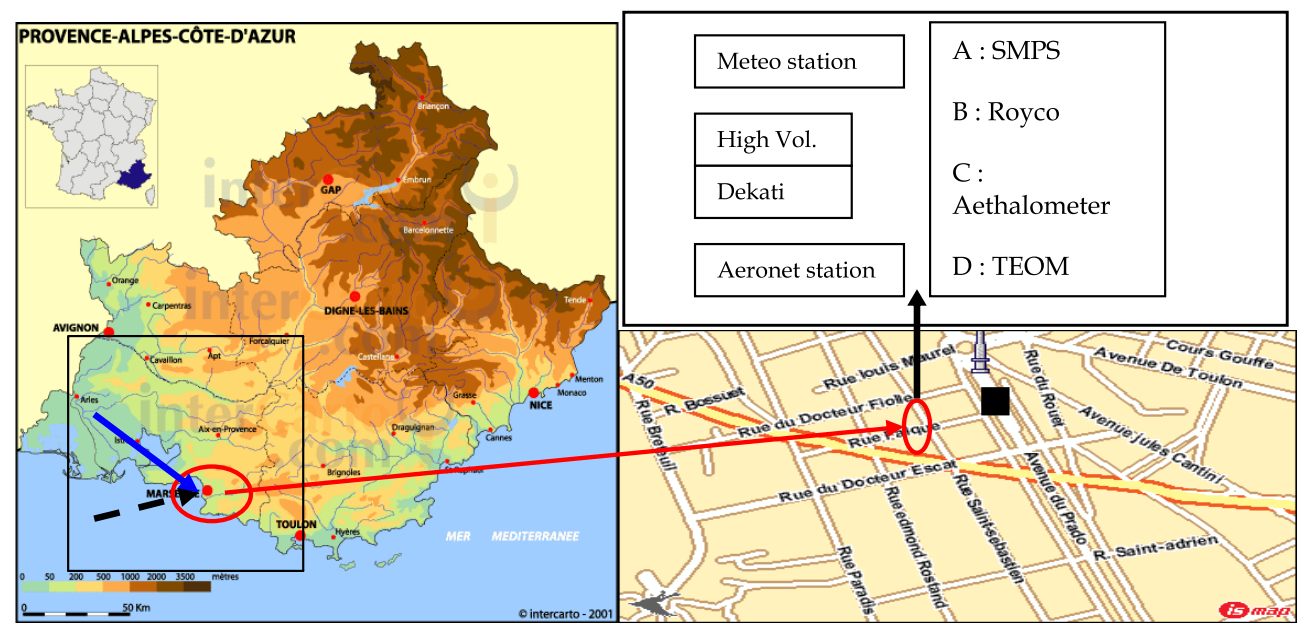

Fig. 1. Left: view of the ESCOMPTE domain (small black square), Marseille city (red ellipse); The arrows in the small square indicate the dominant wind directions. Right: Location of the measurement stations: canopy level (red ellipse) and details (above) of the sensors installed on the roof and street level (black square).

This region is characterised by the presence of numerous industrial and urban sources of primary and secondary pollutants and by specific summer meteorological conditions, mainly anticyclonic with strong solar radiation, both aspects leading to a high probability of photochemical pollution events (Cros et al., 2004). The study of these photochemical events was one of the two main objectives of the campaign and, when favourable conditions for photochemical processes were forecasted, Intensive Observation Period (IOP) was decided. Four situations: 14-15 June (IOP 1), 21-26 June [IOP 2a (21-23) and 2b (24-26)], 2-4 July (IOP 3 ) and 10-12 July (IOP 4), corresponded to these conditions.

\subsection{Experimental set up}

The building where the urban measurement station was installed is located along a one-way street canyon (Rue St Sebastien) and nearby (100 m) a two-way road (Prado avenue), both 
with intense traffic (Fig.1). The measurement station was installed on the roof of the building, $30 \mathrm{~m}$ above street level, and composed of one Scanning Mobility Particle Sizer (SMPS TSI : 3071 classifier and 3022 CPC) measuring between 14 and $720 \mathrm{~nm}$, one optical counter (Royco) between 0.5 and $15 \mu \mathrm{m}$, two TEOMS (Rupprecht and Patachnick) with 1 and $10 \mu \mathrm{m}$ cut-off inlets (heated at $50^{\circ} \mathrm{C}$ ) and one aethalometer (Magee Scientific AE 14) for quasi-real time BC concentration measurements. A total filter and two cascade impactors (a 6 stages "High Vol Sierra" between 0.5 and $10 \mu \mathrm{m}$ and 13 stages low pressure "Dekati" between 0.03 and $10 \mu \mathrm{m}$ ) were used to collect particles on filters for chemical analyse. Meteorological parameters were locally measured with an automatic station while radiative measurements were provided by a specific system located on the roof of a neighbouring building. One Aeronet station was also installed during the experimental period. Gas measurements $\left(\mathrm{CO}, \mathrm{NO}_{\mathrm{x}}\right)$ were taken at street level on the Prado avenue, by AIRMARAIX (now ATMOPACA), the local air pollution network.

\subsection{Data acquisition}

All these systems were systematically run during IOPs but also outside these specific periods, except the Dekati low pressure impactor. The SMPS and the optical counter provide number concentrations and size distributions in their specific size domains. Each one was set up to give one concentration and one distribution every 15 minutes, resulting from the average of 3 successive scans lasting 4 minutes each. Every 30 minutes, two mass concentrations $\left(\mu \mathrm{gm}^{-3}\right)$ were available with the two TEOM. The aethalometer provided one $\mathrm{BC}$ concentration $\left(\mathrm{ngm}^{-3}\right)$ every 3 minutes and five successive values were averaged to obtain one measurement every 15 minutes. In order to obtain enough material for the chemical characterization and according to their respective flow rates, the total filter, High Vol and Dekati impactors sampled 3, 6 and 10 hours, respectively. The black and organic carbon contents were determined by the 2-step thermal analysis method (Cachier et al., 1989) of the total filters, generally two, daily sampled (Cachier et al., 2005). The ionic composition was determined by chromatographic analysis (Putaud et al., 2004) of the filters impacted with the "Dekati" low pressure cascade impactor.

\section{Results and discussion}

\subsection{PM mass concentrations}

PM10 and PM1 concentration measurements started the 16/06 and 18/06, respectively, and were then monitored during the whole campaign. Over the 16/06 - 13/07 period, the average PM10 concentration (Fig. 2a) is $(28 \pm 5) \mu^{-3}$, a value of the same order as those obtained in various European urban zones, generally comprised between 20 and $45 \mu \mathrm{gm}^{-3}$ (Harrison et al., 2001; Perez et al., 2008; Pey et al., 2010; Putaud et al., 2004; 2010; Schwarz et al., 2008), according to the site (kerbside, downtown, suburbs), the season or to specific meteorological conditions. Averaged over $24 \mathrm{~h}$ only, the concentration varies between 11

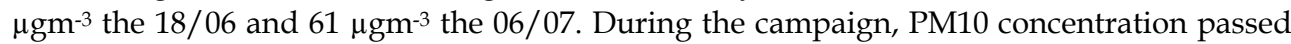
once only (06/07) beyond the EU standard 24-hour limit value of $50 \mu^{-3}$, but reached,

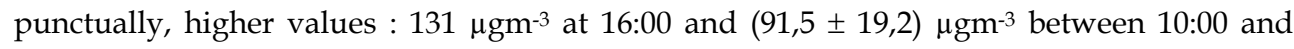
19:00, on July 6, a "non-IOP" day. 


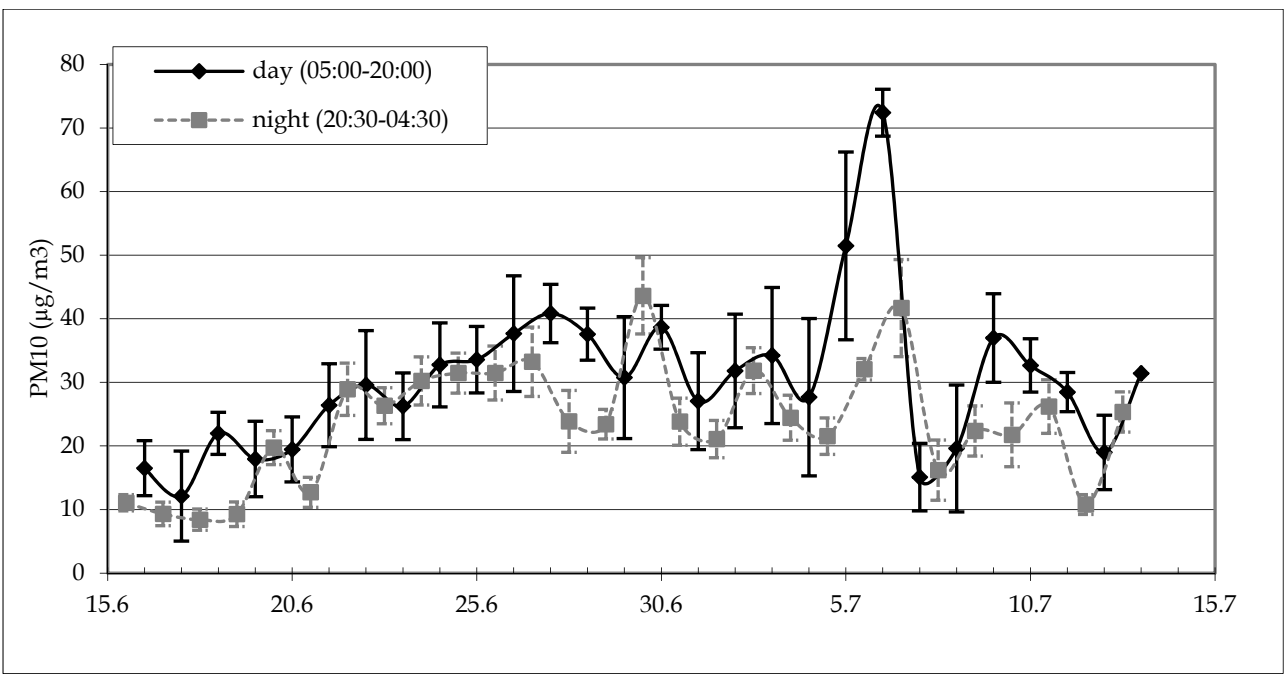

Fig. 2a. PM10 mean concentrations recorded during the campaign.

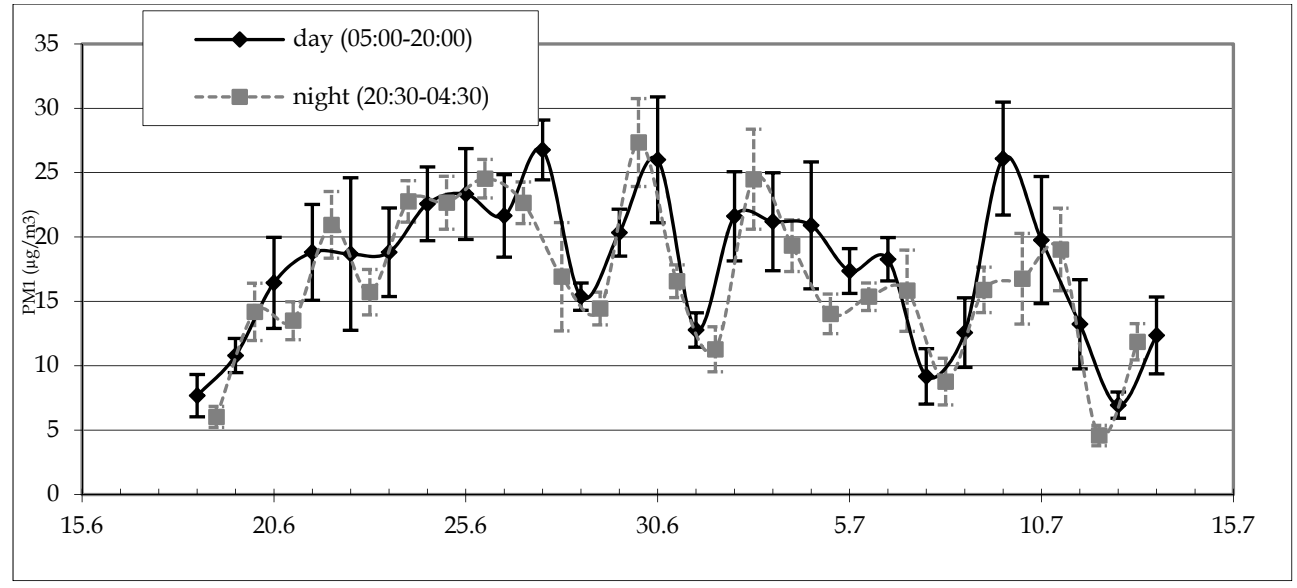

Fig. 2b. PM1 mean concentrations recorded during the campaign.

The PM1 mean concentration (fig. $2 b$ ) over the $18 / 06-13 / 07$ period is $(17.5 \pm 2.1) \mu \mathrm{gm}^{-3}$ and varies between 7 and $26 \mu \mathrm{gm}^{-3}$ when averaged over 24 hours. These values are comparable with those obtained in Barcelona and reported by Viana et al. (2005), Pey et al. (2010) between 7 and $20 \mu \mathrm{gm}^{-3}$, or by Gugliano et al. (2005) in Milano, around $15.3 \mu \mathrm{gm}^{-3}$ in summer. Nevertheless, as for PM10, PM1 punctually reached higher values: $56 \mu_{\mathrm{gm}^{-3}}$ at 06:00 on June 22 or $(35.6 \pm 3.7) \mu^{-3} \mathrm{gm}^{-3}$ between 7:00 and 13:00 on June, 30. It must be noted that the higher concentrations were not recorded the same day than those of PM10 but, as for PM10, during non "IOP days". This shows that the IOP conditions do not correspond to a systematic enhancement of PM10 and PM1 concentration, and that PM10 and PM1 may evolve differently. 
Analysed over 24 hours, PM10 and PM1 present both a strong increase (around $50 \%$ to $60 \%$ of the background values) in the morning, around 7:00 to 8:00, linked to the traffic rush. But both are also characterised by large daily variations, during and outside IOP periods. For PM10 the standard deviation represents, in average, $47 \%$ of the mean daily value and reach $67 \%$ on July, 4 . The corresponding values for PM1 are $36 \%$ and $54 \%$ on June, 22. Despite the fact that PM10 includes PM1, sometimes PM10 increases while PM1 decreases and conversely (Fig. 3). In the first case this means that coarse particles $(>1 \mu \mathrm{m})$ are mainly generated and, conversely, that fine particles $(<1 \mu \mathrm{m})$ are generated in excess, in the second case. This simply confirms that the main PM10 and PM1 sources are different.

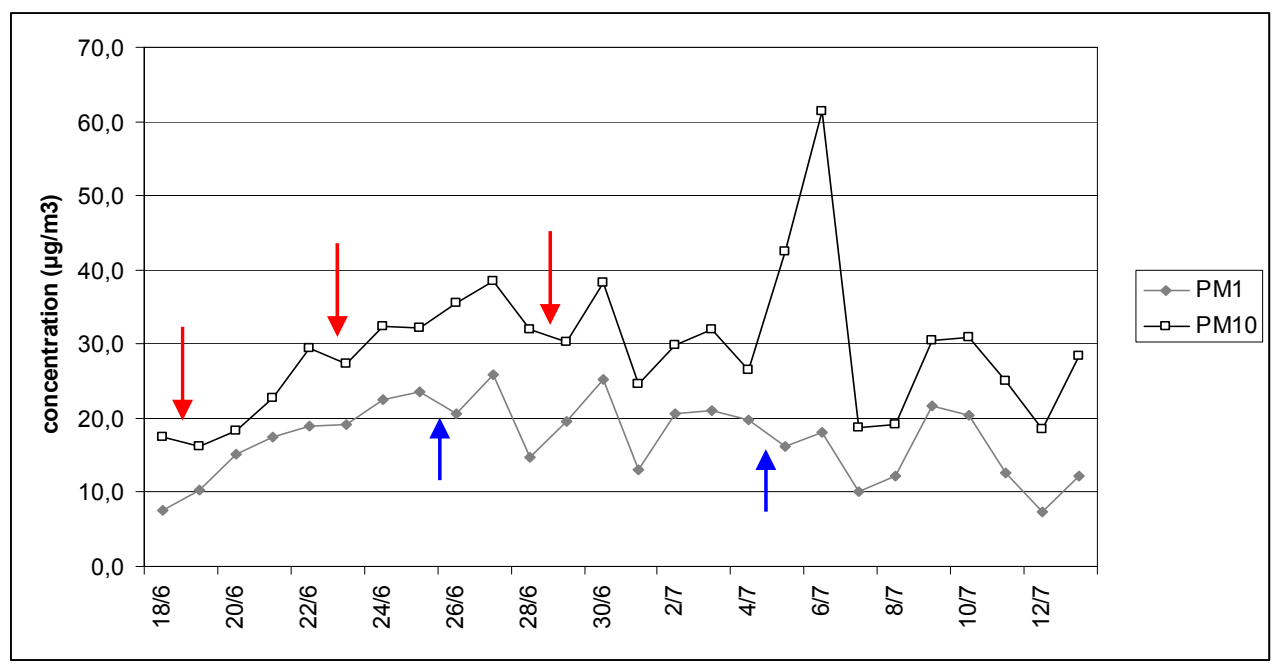

Fig. 3. Day to day comparison of PM10 and PM1 evolutions. The red arrows indicate the cases where PM1 increase while PM10 decrease, the blue arrows indicate the reverse situation.

The PM10 and PM1 concentrations depend also highly on various other factors, of which the meteorological conditions. Indeed, both wind and humidity affect differently the fine and coarse particles.

The daily comparison between the mean values of concentration and wind velocity (V), (Fig. 4.a) shows that PM10 and V are not correlated $\left(R^{2}=0.01\right)$, that PM1 decreases slightly when $\mathrm{V}$ increases $\left(\mathrm{R}^{2}=0.41\right)$ whereas the coarse fraction (PM10 - PM1) tends to increase with V $\left(R^{2}=0.58\right)$. This indicates that the wind velocity tends to disperse the fine particles $(<1 \mu \mathrm{m})$ more efficiently than it generates or raises up to the canopy coarse particles, leading to the non-correlation PM10-wind velocity.

On the other hand, the PM-humidity relationship shows (Fig. 4b) that the fine particles are more humidity dependent $\left(\mathrm{R}^{2}=0.54\right)$ than the coarse $\left(\mathrm{R}^{2}=0.10\right.$ only), indicating a less hygroscopic character of the larger particles. 


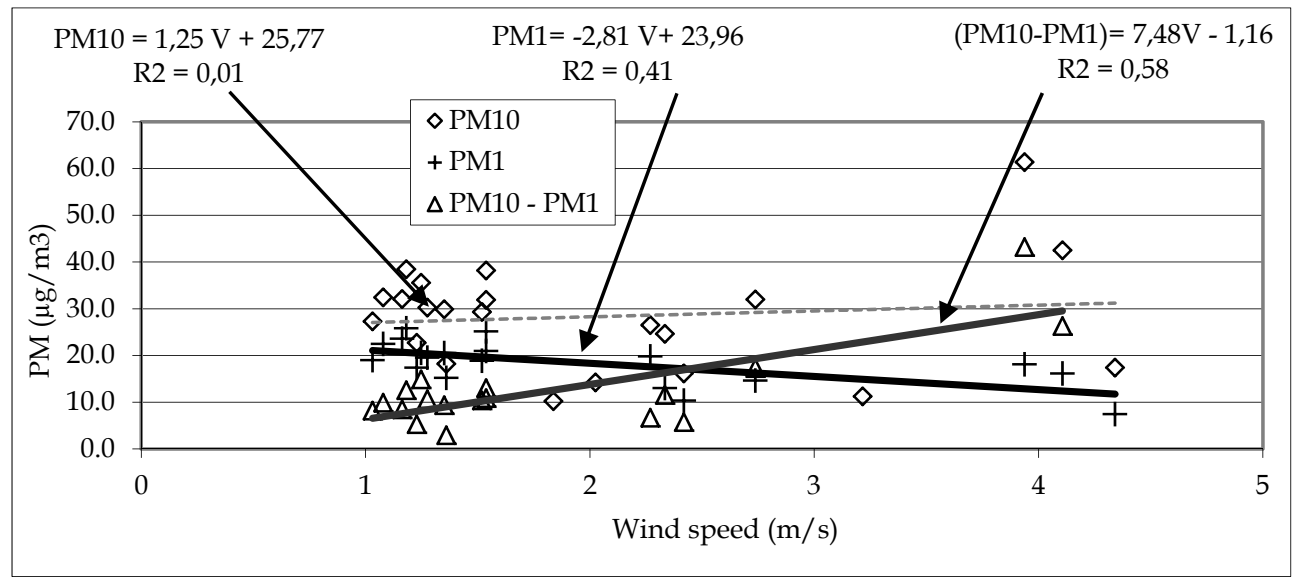

Fig. 4a. PM10, PM1 and (PM10-PM1) versus wind speed.

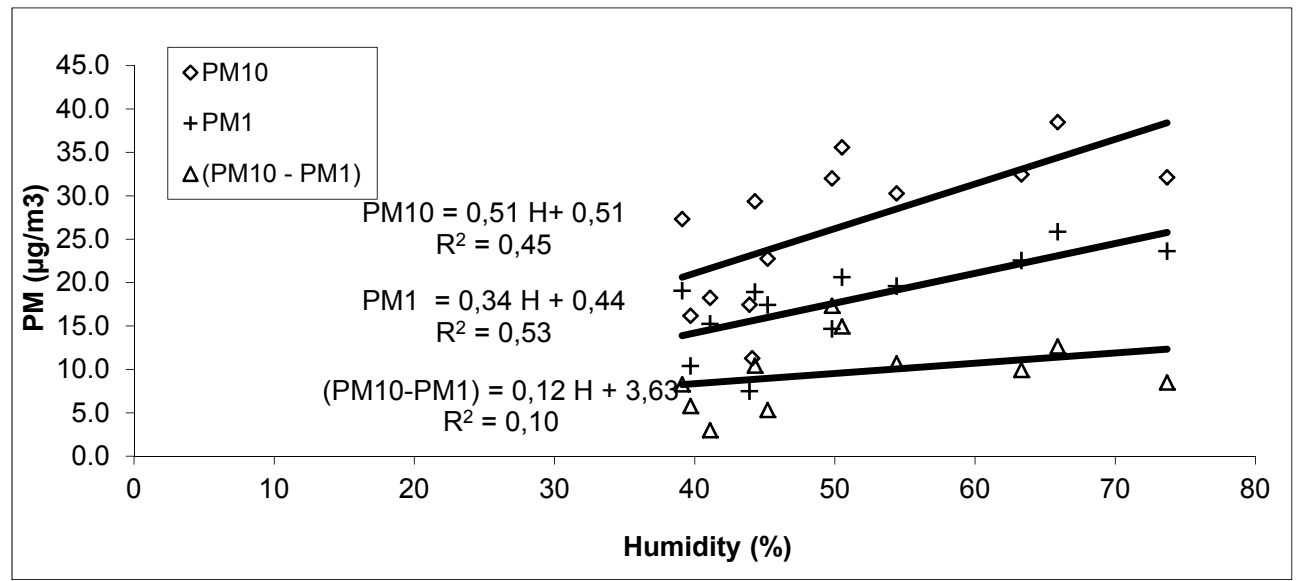

Fig. 4b. PM10, PM1 and (PM10-PM1) versus humidity. 
The comparison between the fine and coarse fractions is generally made through the study of PM2.5/PM10 ratio (Harrison et al., 2001; Keywood et al., 1999; Putaud et al, 2010; Querol et al., 2004; Van Dingenen et al., 2004) and more rarely through the PM1/PM10 ratio. In our case, the PM1/PM10 ratio varies mainly between 0.5 and 0.7 leading to an average value over the whole campaign of $(0.60 \pm 0.12)$. These values are in accordance with those of Gugliano et al. (2005) in Milano, around 0.60, but slightly greater than those of Keywood et al. (1999) for six cities in Australia $(0.50 \pm 0.08)$ or those by Viana et al. (2005), between 0.33 and 0.54 and Perez et al. (2008) between 0.42 and 0.48, both in Barcelona. However, this ratio reached during the campaign higher $(0.85$ the $20 / 06)$ or lower values, $(0.3$ the $06 / 07)$ and increased slightly $(0.69 \pm 0.06)$ during IOPs 2 and 3 , indicating a tendency for IOP periods to produce more fine particles.

By comparison, the average PM2.5/PM10 ratio calculated by Putaud et al. (2004) from measurements in various European regions including rural and urban sites is $(0.73 \pm 0.02)$, but it is précised (Putaud et al, 2010) that this ratio may vary between 0.4 and 0.9 . These large variations make the comparisons difficult but our PM1/PM10 values are not very different of the PM2.5/PM10 ratio, showing that the (PM2.5-PM1) may be estimated around $10 \%$ only of PM10 in our situation. This estimation is comparable with the Pey et al (2009) value (15\% in urban background in Barcelona) and Querol et al. (2004) values who found that the PM2.5-1 contributed between 9 and $21 \%$ to PM10 in their study in different locations of Spain.

Nevertheless, in order to better compare the relative importance of the fine and coarse modes, we calculated the ratio PM1 / (PM10 - PM1) for each of the 24 days with available data.

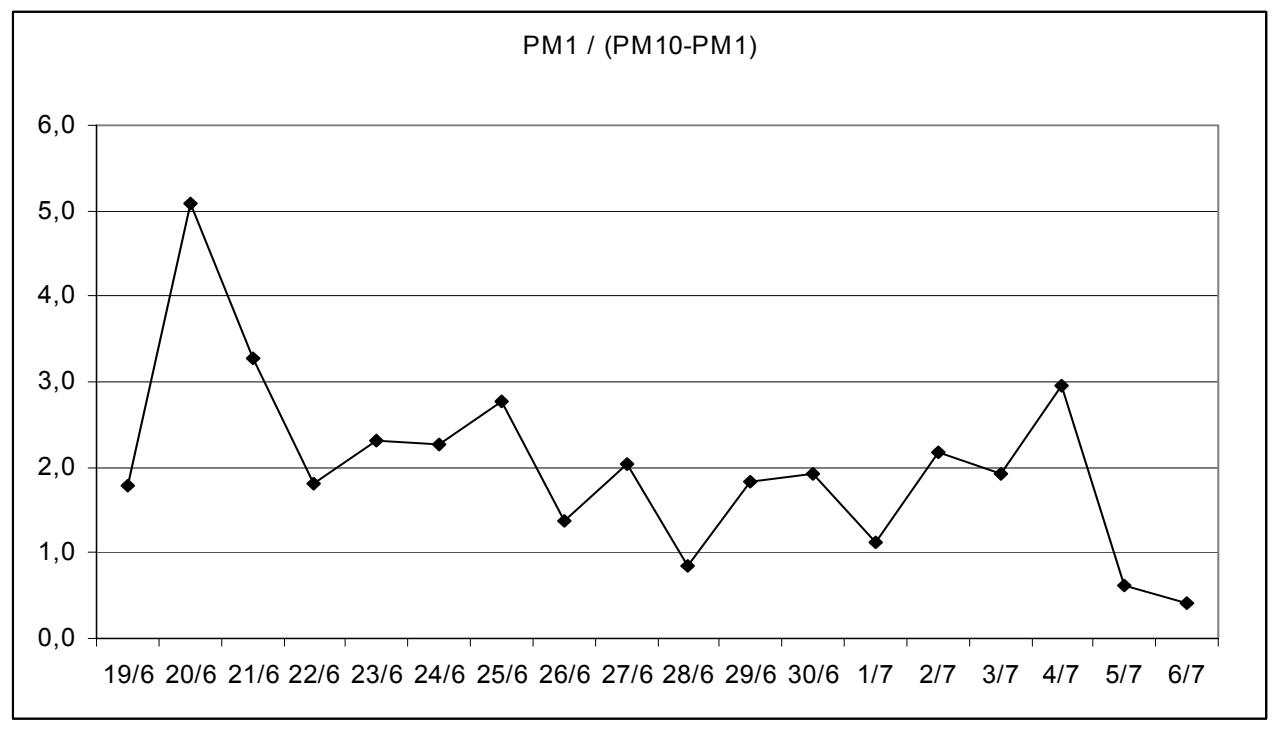

Fig. 5. Ratio PM1/(PM10-PM1) calculated for each day of the campaign. 
The results plotted in Fig. 5 indicate clearly that, in our situation, the fine mode dominates largely, in mass, the coarse mode. Averaged over the whole campaign the ratio is $(1.9 \pm 0.8)$ but it may reach in some cases higher values (3.3 the 21/06 or 5.1 the 20/06), while it is $<1$ for only three days. The fact that the measurements are realised at the canopy level may partially explain this result since the coarse particles are more efficiently deposited and/or less efficiently raised up than the fine particles, in particular during the night and periods of weak winds.

\subsection{Chemical composition}

\subsubsection{Carbon compounds}

Elemental or black carbon (EC or BC) measurements were everyday available through the use of the aethalometer. In parallel with the aethalometer measurements, EC and total carbon (TC) were also daily available through total filters analysed by the thermal method (Cachier et al., 1989). We dispose also of one set of "Dekati filters" sampled during the 23-24 June, in the middle of IOP2, allowing in that case the study of EC and TC mass distribution. Organic carbon (OC) was deduced from the previous values $(\mathrm{OC}=\mathrm{TC}-\mathrm{EC})$.

Over the whole campaign, the average EC concentrations measured by the aethalometer and deduced from the filter analyse are comparable, $(2.93 \pm 0.73)$ and $(2.75 \pm 0.92) \mu^{-3}$, respectively. The TC concentration obtained from the filter analyse is $(9.11 \pm 2.38) \mu_{\mathrm{gm}^{-3}}$, the corresponding OC value is thus evaluated at $(6.37 \pm 1.95) \mu \mathrm{gm}^{-3}$. As for PM1 or PM10, to compare our TC and/or EC measurement results with the large number of those realised in various places in the world is quite difficult because of the specific conditions (meteorological, season, site, duration) that characterise each measurement.

Our TC values are nevertheless comprised in the wide range of those obtained in similar sites (urban or urban background) and summer season, which vary between 4 to $5 \mu^{-3} \mathrm{gm}^{-3}$ in Aveiro (Castro et al., 1999), Helsinki (Viidanoja et al., 2002), Belfast (Jones and Harisson, 2005) or in Oporto (Duarte et al., 2008) and higher values around $19 \mu^{-3} \mathrm{gm}^{-3}$ in Seoul (Kim et al., 1999) or Hong Kong (Ho et al., 2002). The EC/TC ratio is equal to $(0.31 \pm 0.08)$. This ratio is higher than the one (0.17) reported by Pey et al. (2009) for regional background sites in the west coast of Spain but equivalent to those reported by Viana et al. (2007) concerning measurements in Amsterdam and Barcelona, or by Jones and Harrison (2005) in the centre of Belfast and of the same order than those generally found in measurements carried out in similar urban zones, comprised between 0.22 and 0.38 , and reported in Ruellan and Cachier, (2001), Yttri et al. (2007) or Harrison and Yin (2008). For the IOP days only, the results are slightly different. The EC, TC and OC concentrations are respectively $(2.72 \pm 0.94) \mu_{g^{-3}}$,

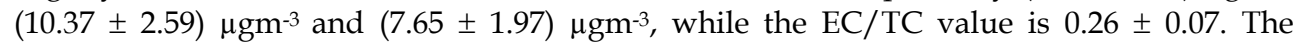
tendency for IOP days is thus an increase of the OC concentrations and, consequently, a decrease of the EC/TC ratio. This tendency is logical since the IOP days are favourable to photochemical processes that favour secondary organic aerosol formation and thus the increase of the OC concentration that is partly composed of secondary organic aerosols.

\subsubsection{Water Soluble Compounds (WSC)}

Seven sets (6 days and 1 night) of 13 filters sampled with the Dekati impactor during IOP1 (14 and 15/06), IOP2 (22, 25d, 25n, and 26/06) and IOP3 (02/07) periods, were analysed by 
ionic chromatography. The amount of the different water soluble compounds in PM10 and PM1 was obtained by summing, for each set of 13 filters, the concentrations measured on each one. Averaged over the 7 samples, nss sulphate $\left(\mathrm{nssSO}_{4}\right)$ is the most abundant $(5.7 \pm 2.3$ $\left.\mu \mathrm{gm}^{-3}\right)$, followed by sea salt $\left(3.81 \pm 1.19 \mu \mathrm{gm}^{-3}\right)$, ammonium and nitrates in equivalent amount, $\left(2.9 \pm 0.4 \mu \mathrm{gm}^{-3}\right)$ and $\left(2.8 \pm 1.1 \mu \mathrm{gm}^{-3}\right)$, respectively, then by the main crustal elements $\left[\mathrm{nss}(\mathrm{Ca}+\mathrm{Mg}+\mathrm{K}) \approx 1.4 \mu \mathrm{gm}^{-3}\right.$. These values are of the same order than those obtained in Barcelona (Viana et al., 2005; Perez et al., 2008) or in other coastal sites in Spain (Querol et al., 2004). These average values hide however the large variations observed on some occasions. The 25 June (IOP $2 \mathrm{~b}$ ) the $\mathrm{nssSO}_{4}$ and $\mathrm{NH}_{4}$ concentrations reach respectively 8.7 and $4.22 \mu \mathrm{gm}^{-3}$, while they are of 1.91 and $1.09 \mu \mathrm{gm}^{-3}$ only the 22 June (IOP 2a). Inversely,

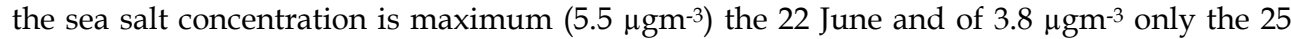
June. These variations result mainly from the very different meteorological conditions of these two days. The 22 , the average humidity during the sampling time is $41.8 \%$ only while it is $78.5 \%$ the 25 . The wind velocity is $5.5 \mathrm{~ms}^{-1}$ in average between 11:30 and 17:30 the 22, and of $2.7 \mathrm{~ms}^{-1}$ only the 25 for the same period. Moreover, the mean wind direction the 22 corresponds to a situation of sea breeze leading to an enhanced production of coarse marine aerosol while the direction is more continental the 25 , coming mainly from the industrial Fos-Berre zone.

\subsubsection{Mass chemical distribution}

The use of the cascade impactor allows the study of the mass distribution of the water soluble compounds for the 7 samples available and of the carbon compounds for the 23-24 July set of filters. $80 \%$ of EC and $69 \%$ of OC are found on the fine mode $(<1 \mu \mathrm{m})$.

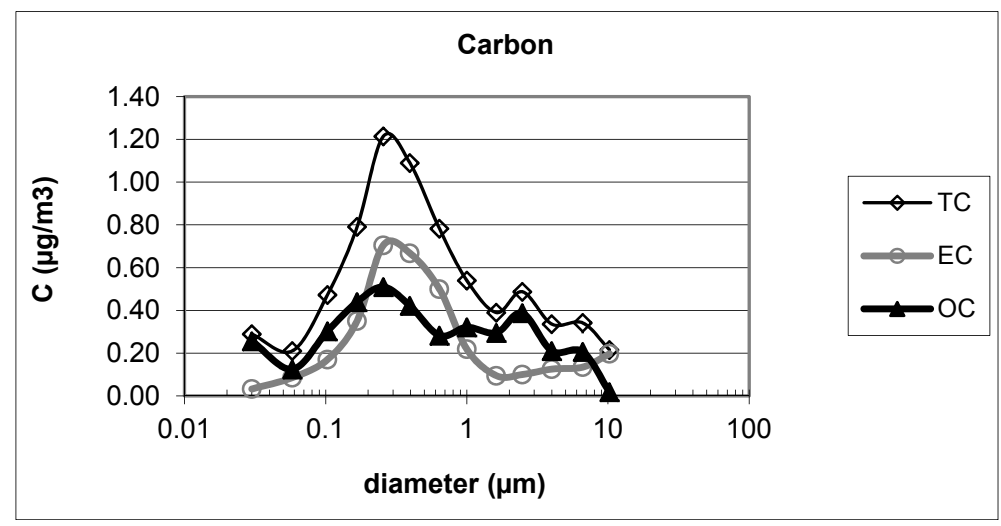

Fig. 6. TC, EC and OC mass size distributions.

Our results (Fig. 6) show that the EC distribution is monomodal and centred on the accumulation mode on particles of diameter comprised between 0.25 and $0.4 \mu \mathrm{m}$, while the OC distribution tends to be bimodal with two relative maximum at 0.25 and $2.5 \mu \mathrm{m}$, respectively. Nevertheless, that distribution must be considered as indicative because they are deduced from the analysis of one set of filters only. 
For the water soluble compounds, the analyse shows that $100 \%$ of ammonium and $94 \%$ of nss-sulphate are found in the fine mode and for the major part on particles of diameter 0.3$0.4 \mu \mathrm{m}$. Sea salt and crustals are classically found on the coarse mode, both at $80 \%$, on particles of diameter 1 and $5 \mu \mathrm{m}$, while nitrate is spread over the whole range but mainly, at $64 \%$, on the coarse mode (Fig.7). Concerning $\mathrm{NO}_{3}$ it must be noted the fine particle amount is mainly due to the distribution obtained during the night $(25 / 06)$ and that its distribution in the coarse mode tends to be bimodal with two maximum around 2.5 and $7 \mu \mathrm{m}$.
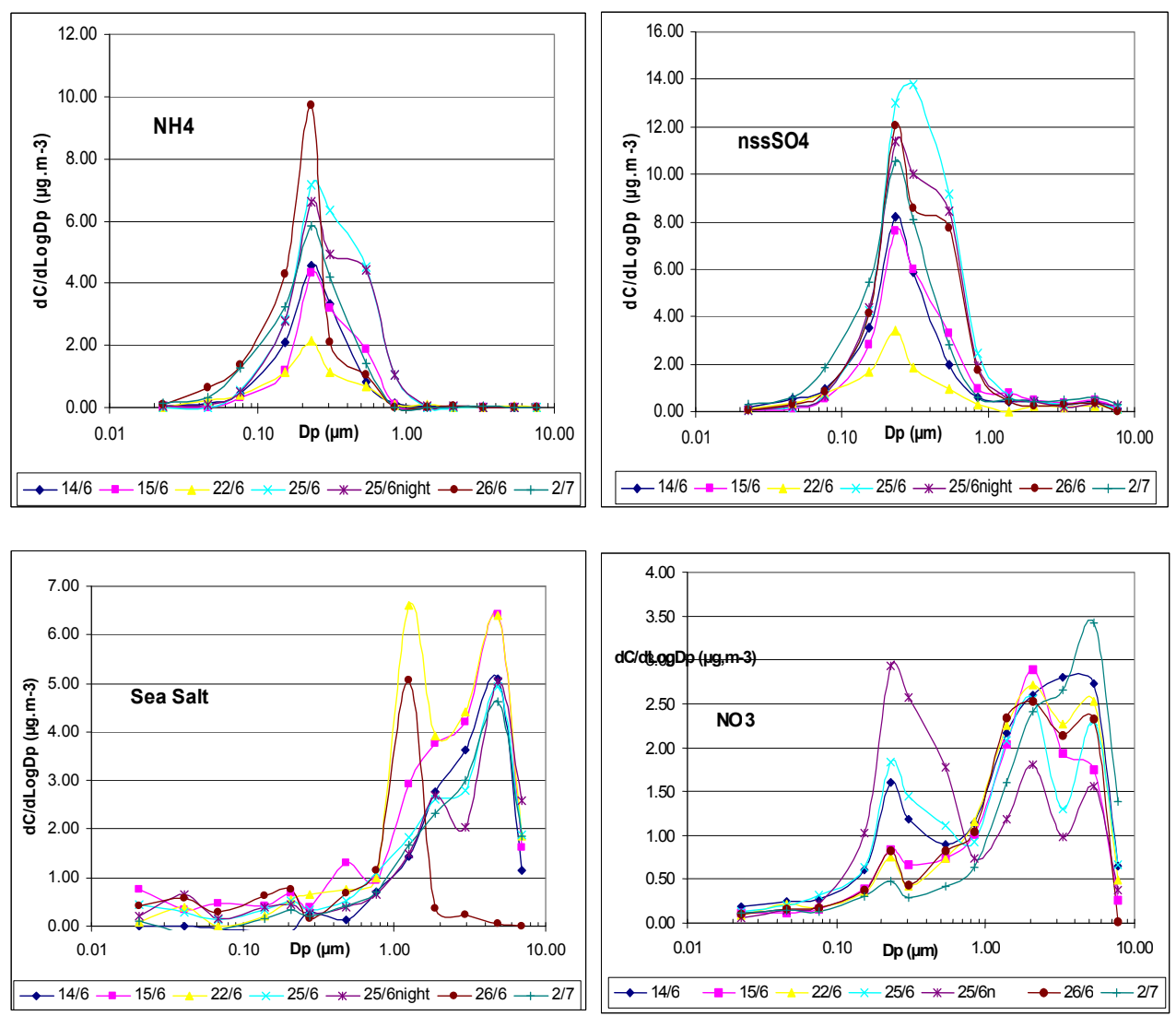

Fig. 7. Mass size distribution of 4 WSC corresponding to the seven sets of filters.

In Fig. 8 are reported the relative percentages of the compounds analysed for PM10, PM1 and PM1-10. 

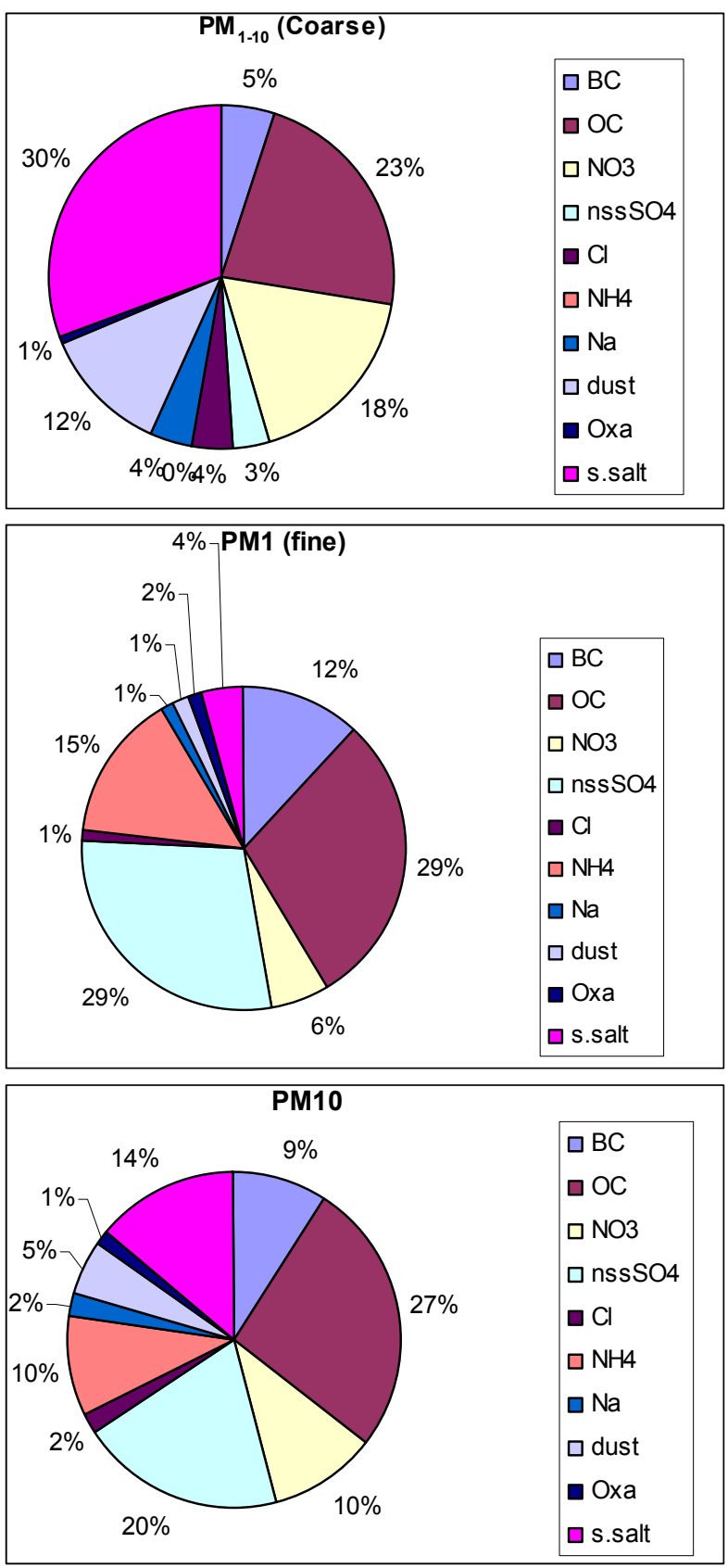

Fig. 8. relative percentages, averaged over the seven sets of filters, of the different compounds in PM10, PM1 (Fine) and PM(1-10) (coarse). 
It can be seen that for PM10 (36\%) as for PM1 (41\%), TC (OC + EC) is by far the major contributor, followed by $\mathrm{nsSO}_{4}, 20 \%$ and $29 \%$, respectively. For PM1-10, sea salt becomes the major contributor (30\%), followed by TC (28\%). Compound by compound, the four more important are $\mathrm{OC}(27 \%)$, nssSO4 $(20 \%)$, seasalt $(14 \%)$ and $\mathrm{NH}_{4}+$ and $\mathrm{NO}_{3}(10 \%)$ for PM10, OC (29\%), $\mathrm{nssSO}_{4}(29 \%), \mathrm{NH}_{4}(15 \%)$ and EC (12\%) for PM1, seasalt,(30\%), OC $(23 \%), \mathrm{NO}_{3}(18 \%)$ and crustals $(14 \%)$ for PM1-10. The comparison between the three distributions shows that, for PM1, the relative parts of carbon (EC and OC), nss $\mathrm{SO}_{4}$ and $\mathrm{NH}_{4}$ increase, while $\mathrm{NO}_{3}$ and sea salt decrease, confirming simply that the first compounds are mainly distributed on the fine particles and conversely for $\mathrm{NO}_{3}$ and sea salt.

\subsubsection{Correlation between WSCs}

We calculated (Table 1) the coefficient of correlation between different WSCs for each set of filters (the 13 filters are considered together) and for each day. When $\mathrm{R}^{2}$ is very high $(>0.8)$, this means that the two compounds are found on the same size category, fine or coarse, and more precisely on the same narrow size range.

\begin{tabular}{|c|c|c|c|c|c|c|c|}
\hline $\mathrm{R}^{2}$ & $14 / 06$ & $15 / 06$ & $22 / 06$ & $25 / 06 \mathrm{D}$ & $25 / 06 \mathrm{~N}$ & $26 / 06$ & $02 / 07$ \\
\hline $\mathrm{NH}_{4}-\mathrm{nssSO}_{4}$ & 0.99 & 0.98 & 0.98 & 0.98 & 0.99 & 0.44 & 0.98 \\
\hline $\mathrm{NH}_{4}-\mathrm{NO}_{3}$ & 0.05 & 0.07 & 0.32 & --- & 0.56 & 0.18 & 0.30 \\
\hline $\mathrm{Na}-\mathrm{NO}_{3}$ & 0.84 & 0.86 & 0.45 & 0.48 & --- & 0.34 & 0.73 \\
\hline $\mathrm{Na}-\mathrm{Cl}$ & 0.58 & 0.55 & 0.97 & 0.35 & 0.35 & 0.06 & 0.40 \\
\hline
\end{tabular}

Table 1. Coefficient of correlation between different WSCs.

It is clearly the case for $\mathrm{NH}_{4}$ and nss $\mathrm{SO}_{4}$ that are, except the 26/06, both localised on particles of diameter comprised between 0.3 and $0.5 \mu \mathrm{m}$ and classically linked as $\left(\mathrm{NH}_{4}\right)_{2} \mathrm{SO}_{4}$. It is also the case for $\mathrm{Na}$ and $\mathrm{NO}_{3}$ the 14 and 15 June, associated as $\mathrm{NaNO}_{3}$ in coarse particles or $\mathrm{Na}$ and $\mathrm{Cl}(\mathrm{NaCl})$ the 22 June, also on the coarse mode. On the contrary, when $\mathrm{R}^{2}$ is weak, the two compounds are distributed differently (coarse and fine). However, even when $\mathrm{R}^{2}$ calculated over the whole size range is weak, it is possible that the corresponding compounds be associated only in the fine or in the coarse mode. For example, $\mathrm{R}^{2}$ calculated for $\mathrm{NH}_{4}$ and $\mathrm{NO}_{3}$ over the fine mode only, reach values $>0.90$ the 14/06, 15/06 or 25/06 of June, indicating the presence of ammonium nitrate in the fine mode. The 26/06 is characterised by a weak ammonium-nss-sulphate correlation $\left(\mathrm{R}^{2}=0.44\right)$ and no ammonium-nitrate correlation. According to wind direction and back-trajectories, the air masses on that day were exclusively of marine origin that could explain the weak correlations, as it was previously noticed in the same region and under similar conditions by Sellegri et al. (2001).

\subsection{Particle concentrations and size distributions}

During the campaign, the SMPS system was set up to provide one average Size Distribution (SD) every 15 minutes, derived from 3 SD lasting 4 minutes each. From these SD, other 
parameters were deduced (total concentrations, day average $\mathrm{SD}, \ldots$ ), according to the analysis conducted. Total $\mathrm{dN}$ or $\mathrm{dN} / \mathrm{dLogD}$ concentrations were obtained by summing the concentrations measured for each size range. In Fig. 9 are plotted the day and night average of the $\mathrm{dN}$ concentrations obtained at the canopy level for 17 days and 10 nights during the campaign.

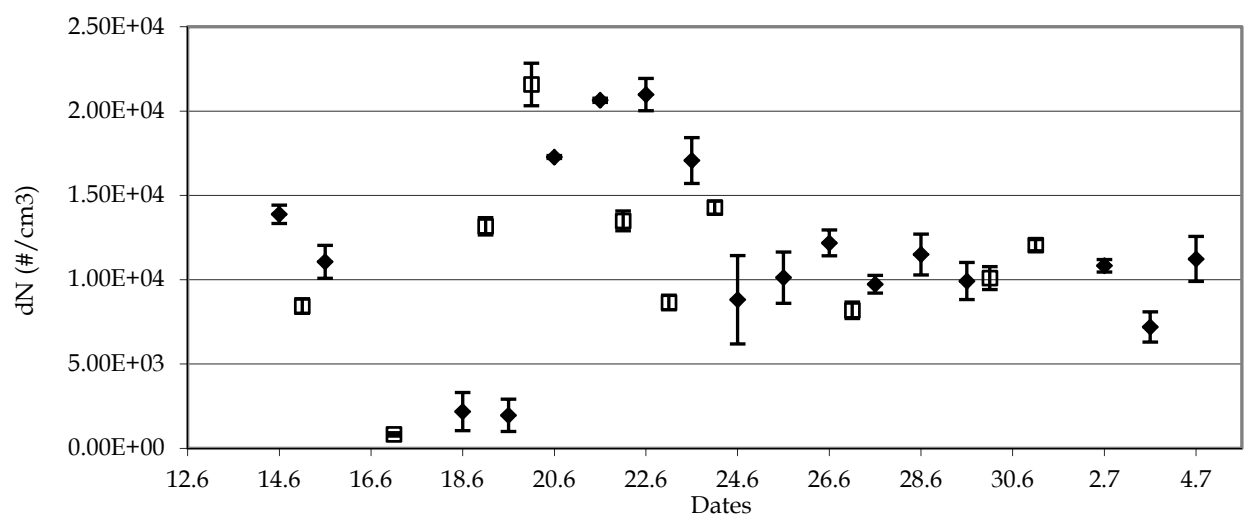

Fig. 9. Plot of the day (black stars) and night $\mathrm{dN}$ average concentrations (with standard deviation) recorded during the campaign.

These concentrations vary mainly between $0.75 .10^{4}$ and $1.4 .10^{4} \mathrm{~cm}^{-3}$, except in two occasions. The 18/6 and 19/6 the concentrations are lower because these two days are characterised by strong winds $\left[(8 \pm 1) \mathrm{ms}^{-1}\right.$ in average against $\approx 2 \mathrm{~ms}^{-1}$ for the other days] that disperse very efficiently the fine particles, as already noted for the PM1 concentration. The 21/6 and 22/6, which are the first days of the IOP2, the concentrations are on the contrary higher. Averaged over the whole campaign the concentration is $(1.3 \pm 0.5) 10^{4} \mathrm{~cm}^{-3}$ including the 4 specific situations mentioned before or $(1.3 \pm 0.2) .10^{4} \mathrm{~cm}^{-3}$, without. This value, that may be considered as the background value at the canopy level for the corresponding period and site, is of the same order than those measured in Prague $\left(1.1810^{4} \mathrm{~cm}^{-3}\right)$ by Salma et al. (2011), in Augsburg (1.22 $\left.10^{4} \mathrm{~cm}^{-3}\right)$ by Birmili et al. (2010) or in other urban sites (London, Leipzig or Milano), comprised between 0.7.104 and 2.4.104 $\mathrm{cm}^{-3}$ ) and reported in Putaud et al., (2004, 2010). Our value is however largely lower than those measured at kerbside, which vary between $4.0 .10^{4}$ and $6.0 .10^{4} \mathrm{~cm}^{-3}$, Putaud et al., $(2004,2010)$ or by Yue et al., $(2010), 2.910^{4} \mathrm{~cm}^{-3}$ in average in Ghangzoua, during summer pollution episodes. This simply shows that, in urban zone and in summer season, the particles produced by the traffic at street level are partially dispersed before reaching the canopy and that measurements made at canopy level are likely more representative, as input values for regional models, than results obtained at street level. It must also be noted that IOP days, as it was already the case for the PM measurements, do not correspond systematically to the higher concentration values. Indeed, the concentrations obtained during the IOP1, 2b and 3 are of the same order than those of "non-IOP" days. 
If these daily average values give a quite good indication of what is expected at the canopy level of a great coastal urban area in summer and may be considered as useful input values for modelling purpose at local and regional scale, or for comparison with particle emission inventories in urban zone, they hide nevertheless the large variations that occur generally during a day.

In Fig. 10 are plotted the background estimated value $\left((1.3 \pm 0.5) 10^{4} \mathrm{~cm}^{-3}\right.$ - dot point line) and the variations recorded, as an example, the 21 June. Two parts, marked by ellipse on the figure, are typical and detected every day. The part 1 corresponds to the morning traffic rush characterised by a strong increase in concentration detected at roof level between 7:00 and 8:00. The part 2 corresponds to the period of lowest concentration due to the conjugate effect of wind speed increase (from $\approx 2 \mathrm{~ms}^{-1}$ in the morning to $\approx 4-5 \mathrm{~ms}^{-1}$ in the afternoon), often linked to the afternoon sea breeze regime, and the vertical development of the boundary layer that disperse very efficiently the particles.

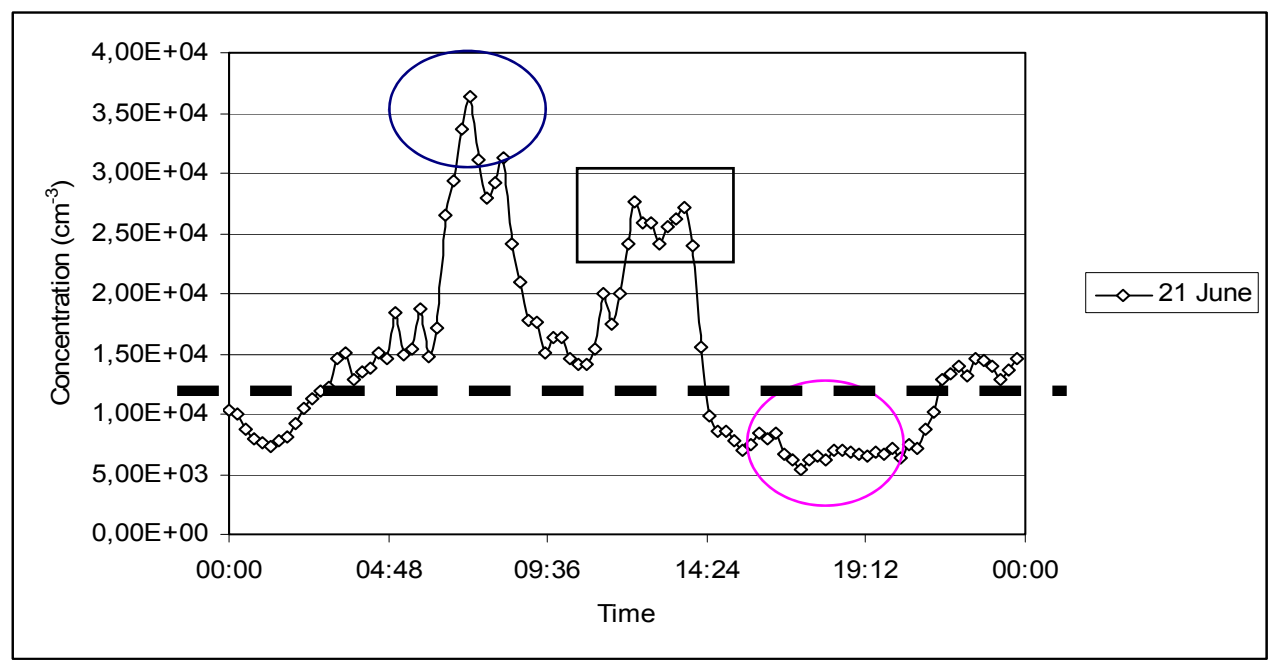

Fig. 10. Example of 24 hours evolution of the fine particles concentration. Ellipses blue and pink mark the maximum and minimum daily observed. The black rectangle mark a specific case of secondary aerosol production.

The peak around 12:00, discussed in detail in Despiau and Croci (2007), is more specific. It is independent of any traffic rush but corresponds to the signature of secondary aerosol production process that occurs in special conditions of wind direction, humidity and radiation. For the six days where that specific peak was detected (hereafter "SPD", Secondary Production Day), the $\mathrm{dN}$ average concentration is $(1.12 \pm 0.7) 10^{4} \mathrm{~cm}^{-3}$ while it is of $(1.05 \pm 0.4) 10^{4} \mathrm{~cm}^{-3}$ for "normal" days (hereafter "ND"). These values remain of the same order than those indicated in the previous paragraph. This means that the diurnal average values remain practically constant, even when a specific process occur, and then do not allow to consider short time variations. Indeed, during the morning rush, the mean of the 
concentration maximum is around 3 times the previous value: $(3.3 \pm 1.7) 10^{4} \mathrm{~cm}^{-3}$ while during the afternoon the concentration is only one half of the mean diurnal value.

The $\mathrm{dN}$ or $\mathrm{dN} / \mathrm{dLogD}$ shape of the particle size distributions gives also useful indications about the characteristics of the particles. In Fig. 11 are reported the averaged size distributions obtained during the night (9 nights between 20:00 and 06:45), during the 6 days with secondary production (SPD) and during the "normal" 10 days (ND). The normal and secondary production days differ mainly by their diameter mode, $(93.0 \pm 15.5) \mathrm{nm}$ for ND, $(40 \pm 4) \mathrm{nm}$ only for SPD. On the contrary, the mode concentrations are of the same order (1.24 \pm 0.5$) 10^{4} \mathrm{~cm}^{-3}$ for ND, and (1.46 \pm 0.94$) 10^{4} \mathrm{~cm}^{-3}$, for SPD. In-between (ND) and (SPD) is the average night distribution with a mode diameter about $55 \mathrm{~nm}$ and a concentration around $1.310^{4} \mathrm{~cm}^{-3}$.

The size distributions corresponding to the specific periods illustrated by the Fig. 10 are also characteristic and largely different from the mean size distributions of Fig. 11.

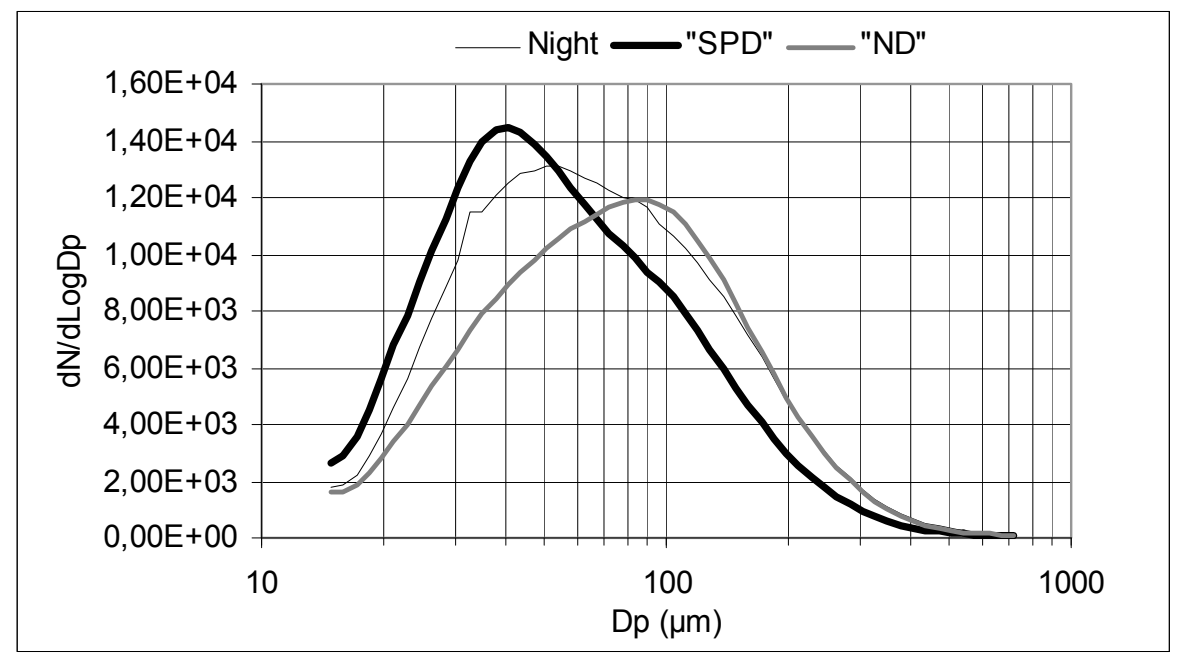

Fig. 11. Plot of the mean size distribution corresponding to "normal" days (ND), "secondary production day" (SPD) and night.

Since they have been presented in details in Despiau and Croci (2007) we just summarize here their main characteristics. The size distribution of the morning traffic rush are characterized by an increase (factor 3 to 4 with respect to the background values) in concentration of the whole size range of fine particles leading to a monomodal SD with a diameter mode around $100 \mathrm{~nm}$. For those corresponding to the secondary production process, only the concentration of the particles smaller than $70 \mathrm{~nm}$ increases (factor 4 in 30 to 45 minutes) leading to a peak around $35 \mathrm{~nm}$ in average, Fig. 12. 


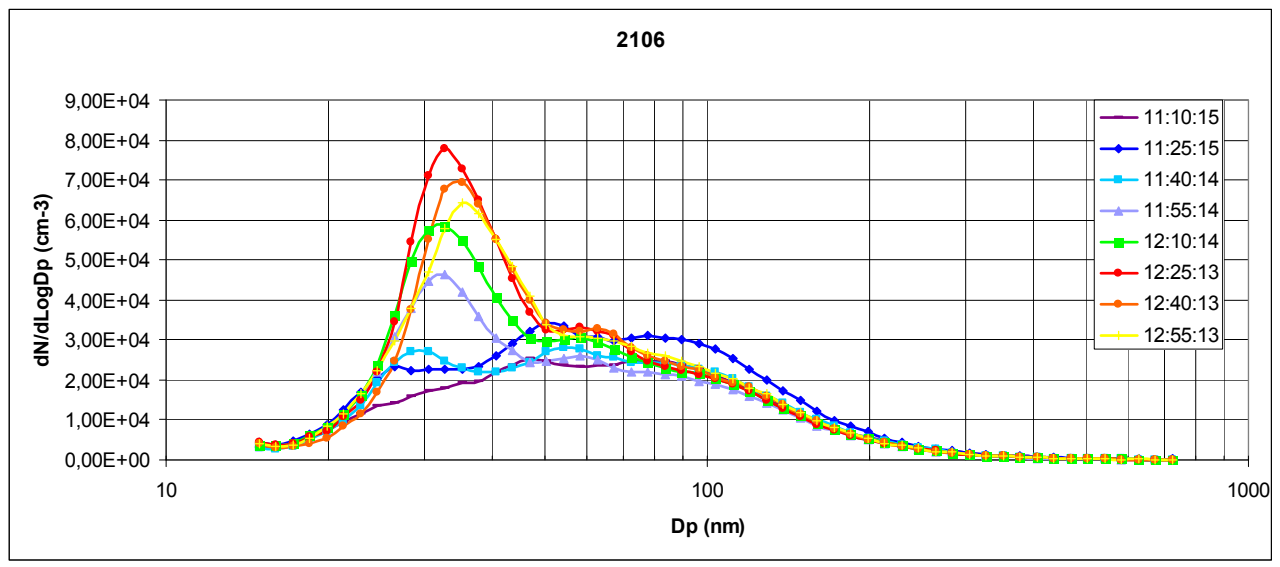

Fig. 12. Evolution of the size distribution in one case (21/06) of secondary aerosol production.

\subsection{Discussion with regard to an "urban signature"}

All the previous results come from measurements realised at the canopy level. They are obviously a mixing of local urban sources and conditions, and of regional transport from the surroundings, that may be, in our situation, as different as marine or anthropogenic origin. It is then difficult to separate precisely the relative influence of the different sources but we estimate that the results obtained reflect quite accurately the main physico-chemical characteristics of the particles at that level and under the specific conditions described.

So, considering the two main questions asked in the introduction, the results obtained show clearly that there is not a specific physical signature corresponding to the local IOP conditions. Nor the PM10 and PM1 mean concentrations are significantly different (larger or smaller for example) for IOP or non-IOP days. The mean number concentrations or size distributions are not either different. We detected a normal tendency for enhanced concentration in OC during IOP days but without conduct to mean concentrations significantly different $\left(7.67 \pm 1.97 \mu \mathrm{gm}^{-3}\right.$ against $\left.6.37 \pm 1.95 \mu \mathrm{gm}^{-3}\right)$. We cannot conclude about the WSC chemical composition since we measured only during IOP days but it seems unlikely that the chemical composition be very different, except perhaps for compounds that would mainly result, as OC, from strong photochemical processes.

It is nevertheless possible to describe the main physico-chemical characteristics of the aerosol particles at the canopy level of a great Mediterranean conurbation, in summer. These local conditions may appear restrictive but we believe that similar conditions may be found at least in the Mediterranean area where various great cities are coastal cities (Barcelona, 
Valencia, Genoa, Roma, Athens or north African cities, ...) and probably in other coastal regions in the world where conditions leading to photochemical processes would be fulfilled. For modelling at large scale and over long periods and probably to compare with emission inventories at urban zone scale, the order of magnitude of the mean values obtained should be useful. They may be summarized in terms of PM10 and PM1

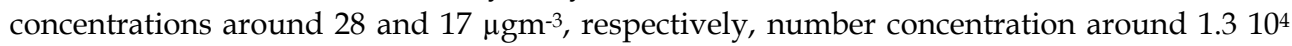
$\mathrm{cm}^{-3}$ and a unimodal size distribution with a diameter mode around $100 \mathrm{~nm}$. Always in terms of order of magnitude, the concentrations of the main elements may be estimated at $10 \mu \mathrm{gm}^{-3}$ for carbon compounds $\left(7 \mu \mathrm{gm}^{-3}\right.$ for OC and $3 \mu \mathrm{gm}^{-3}$ for EC), $6 \mu \mathrm{gm}^{-3}$ for nss $\mathrm{SO}_{4}, 4$ $\mu \mathrm{gm}^{-3}$ for sea salt and $3 \mu \mathrm{gm}^{-3}$ for ammonium and nitrate. Ammonium and nssSO 4 are distributed over the fine particles, sea salt mainly over coarse particles while nitrate and carbon compounds are spread over the whole size range.

However, if more precise information are needed for modelling at local scale and/or short time period for example, or to verify estimations of inventory emissions at short time scale, the previous average data become unreliable. It is then necessary to take into account specific characteristics like those linked to the morning traffic rush, the afternoon decrease, the secondary aerosol processes or very particular meteorological conditions. All those particular situations last about 2 to 3 hours and are characterized by very different values of PM or dN concentrations, shape of size distribution or mode diameter. Inversely, a significant modification of the chemical composition over the same time scale is quite unlikely since this would suppose a change in the sources that supply the particles and because the chemical modification of the particles is a process much more slow than $\mathrm{dN}$ or PM concentration variations. During the morning traffic rush or the SPD events, the $\mathrm{dN}$ and PM concentrations will increase strongly while the corresponding sources do not change.

Nevertheless, the meteorological conditions play a crucial role that must be accounted for, especially at local scale. The wind velocity and the vertical development of the boundary layer will influence the afternoon decrease. The wind velocity and direction will contribute to the transport over the city of particles from different origin (marine or industrial in our situation). The amount of radiation will influence the production of secondary aerosols while the humidity will influence the mass concentration or the chemical composition. So, except for the morning traffic rush that is well characterized whatever the meteorological conditions, most of the other situations must be envisaged only after considering the main meteorological conditions: wind velocity and direction, radiation and humidity.

\section{Conclusion}

The measurements carried out in urban zone during the ESCOMPTE campaign allowed us to study, at roof level and summer season, the physico-chemical characteristics of aerosol particles.

Most of the number or mass concentrations, chemical composition or size distributions results obtained during this campaign, are in agreement with those recorded in large urban zones and reviewed in the papers by Putaud et al. $(2004,2010)$. Nevertheless, the PM1 and 
PM10 mass concentrations are characterized by strong daily variations, they may sometimes evolve in opposite sense and the fine mode $\left(D_{p}<1 \mu \mathrm{m}\right)$ is largely dominant in mass compared to the coarse mode. The fine particles are more dispersed by the wind and are more humidity dependent than those of the coarse mode.

During the campaign, the OC concentration was the higher, followed by nss sulphate, sea salt, ammonium nitrates and EC in equivalent concentration and finally by the main crustal elements. EC, nss sulphate and ammonium are found on the fine mode, sea salt and crustal elements on the coarse mode while nitrates and OC are spread over the two modes. The OC concentration tends to increase in the fine mode during the periods of strong photochemistry conditions that produce secondary aerosols.

The background number concentration at the canopy level has been estimated around (1.3 \pm 0.5) $10^{4} \mathrm{~cm}^{-3}$. This value is significantly lower than concentrations measured at kerbsite but do not vary significantly according to the environmental conditions, except when the day average wind velocity go beyond 4 to $5 \mathrm{~ms}^{-1}$.

That background value hide however the large variations observed daily and characterized by a strong increase in the morning, linked to the morning traffic rush, and by a minimum in the afternoon explained by the double dispersion effect of wind and boundary layer dynamics.

On some occasions a peak in concentration resulting from secondary aerosol production has been detected and lead to a size distribution with a mode around $40 \mathrm{~nm}$ while on "normal" days the mode is around $100 \mathrm{~nm}$.

The results obtained also show that it does not exist, at canopy level in urban zone, a typical or characteristic "aerosol particle signature" corresponding to the specific conditions leading to photochemical events. Nevertheless, it is possible to describe a set of average characteristics that might be useful for modelling purposes at large spatial or time scale and to be compared with emission inventories.

For similar considerations at shorter time or spatial scales, it becomes necessary to take into account specific characteristics like the increase in concentration linked to the morning traffic rush, the afternoon decrease linked to the wind velocity and the development of the boundary layer, both every day detected, or, in some particular circumstances, the effect of secondary aerosol production.

For those situations, except for the morning rush, the meteorological conditions influence is obvious. The wind velocity determines the dispersion process, thus the mass and number distributions measured at roof level. The chemical composition may be modified according to wind direction. The relative humidity modify the mass distribution, while the radiation level may contribute to photochemical phenomenon and secondary aerosol production.

\section{Acknowledgements}

This work has been funded by two French national research programmes : PNCA and PRIMEQUAL-PREDIT and by the ADEME agency. The author would thanks very specially H. Cachier and J.P. Putaud for their help in chemical analyse. 


\section{References}

Birmili, W., Heinke, K., Pitz, M., Matschullat, J., Wiedensohler, A., Cyrys, J., Wichmann, H.E., and Peters, A., (2010). Particle number size distributions in urban air before and after volatilisation, Atmos. Chem. Phys., 10, 4643-4660.

Builtjes, P.J.H., Borrego, C., Carvalho, A.C., Ebel, A., Memmesheimer, M., Feichter, H., Münzeberg, A., Schaller, E. \& Zlatev, Z. (2003). Global and regional atmospheric modelling, overview of subproject GLOREAM. In Towards Cleaner Air for Europe Science, Tools and Applications, P.M. Midgley and M. Reuther ed., 139-164.

Cachier, H., Aulagner, F., Sarda, R., Gautier, F., Masclet, P., Besombes, J.L., Marchand, N., Despiau, S., Croci, D., Mallet, M., Laj, P., Marinoni, A., Deveau, P.A., Roger, J.C., Putaud, J.P., Van Dingenen, R., Dell'acqua, A. Viidanoja, J., Martins-Dos santos, S., Liousse, C., Cousin, F., Rosset, R., Gardat, E., \& Galy-Lacaux, C. (2005). Aerosol studies during the ESCOMPTE Experiment : an Overview. Atmospheric Research, 74, 547-563.

Cachier, H., Brémond, M.P. \& Buat-Menard, P. (1989). Determination of atmospheric soot carbon with a simple thermal method. Tellus 41B, 379-390.

Castro, L.M., Pio, C.A., Harrison, R.M., \& Smith, D.J.T.(1999). Carbonaceous aerosol in urban and rural European atmospheres: estimation of secondary organic carbon concentrations. Atmospheric Environment 33, 2771-2781.

Charlson, R.J., Schwartz, S.E., Hales, J.M., Ces, R.D., Coakley Jr., J.A., Hansen, J.E., \& Hoffman, D.J. (1992). Climate forcing by anthropogenic aerosols. Science, 255, 423430.

Cousin, F., Liousse, C., Cachier, H., Bessagnet, B., Guillaume, B. \& Rosset, R. (2005). Aerosol modelling and validation during ESCOMPTE 2001. Atmospheric Environment, 39, 1538-1550.

Cros, B., Durand, P., Cachier H., Dobrinski, P., Frejafon, E., Kottmeier, Perros, P.E., Peuch, V.H., Ponche, J. L., Robin, D., Saïd, F., Toupance, G. \& Wortham, H. (2004). An overview of the ESCOMPTE campaign. Atmospheric research , 69, 241-279.

Despiau, S. \& Croci, D. (2007). Concentrations and size distributions of fine aerosol particles measured at roof level in urban zone. Journal of Geophysical Research, vol. 112, D09212, doi:10.1029/2006JD007228.

Dockery, D.W., Pope, A, Xu, X., Spengler, J.D., Ware, J.H., Fay, M.E., Ferris, B.G. \& Speizer, F.E. (1993). An association between air pollution and mortality in six US cities. New England Journal of Medicine, 329, 1753-1759.

Dockery, D.W. \& Pope, C.A. (1994). Acute respiratory effects of particulate air pollution. Annual revue of Public Health, 15, 107-132.

Duarte, R.M.B.O., Mieiro, C. L., Penetra, A., Pio, C. A. \& Duarte, A. C. (2008). Carbonaceous materials in size-segregated atmospheric aerosols from urban and coastal-rural areas at the Western European Coast. Atmospheric Research, 90, 2-4, 253-263

François, S., Fayet, S., E. Grondin \& Ponche, J.L. (2005). The establisment of the atmospheric emission inventories of the ESCOMPTE program, Atmospheric Research, 74, 1-4, 535. 
Gugliano, M., Lonati, G., Butelli, P., Romele, L., Tardivo, R \& Grosso, M. (2005). Fine particulates (PM 2.5-PM1) at urban sites with different traffic exposure, Atmospheric Environment, 39, 2421-2431.

Harrison, R.M., Yin, J., Mark, D., Stedman, J., Appleby, R.S., Booker, J. \& Moorcroft, S. (200)1. Studies of the coarse particle $(2.5-10 \mu \mathrm{m})$ component in urban atmospheres. Atmospheric Environment, 35, 3667-3679.

Harrison, R.M. \& Yin, J. (2008). Sources and processes affecting carbonaceous aerosol in central England. Atmospheric Environment, 42, 7, 1413-1423.

Ho, K.F., Lee, S.C., Yu, J.C., Zou, S.C. \& Fung, K. (2002). Carbonaceous characteristics of atmospheric particulate matter in Hong Kong. The Science of the Total Environment, 300, 59-67.

Jacobson, M.Z. (2001). Strong radiative heating due to the mixing state of black carbon in atmospheric aerosols. Nature, 409, 695-697.

Jones, A.M. \& Harrison, R.M. (2005). Interpretation of particulate elemental and organic carbon concentrations at rural, urban and kerbside sites. Atmospheric Environment 39, 7114-7126.

Kaufmann, Y.J., Tanré, D. \& Boucher, O. (2002). A satellite view of aerosols in the climate System. Nature, 419, 215-223

Keywood, M.D., Ayers, G.P., Gras, J.L., Gillett, R.W. \& Cohen, D.D. (1999). Relationships between size segregated mass concentration data and ultrafine particle number concentrations in urban areas. Atmospheric Environment, 33, 2907-2913.

Kim, Y.P., Moon, K.C., Lee, J.H.\& Baik, N.J. (1999). Concentrations of carbonaceous species in particles at Seoul and Cheju in Korea. Atmospheric Environment , 33, 2751-2758.

Oberdörster, G. (2000). Toxicology of ultrafine particles : in vivo studies. Philosophical Transactions of the Royal Society of London, A358, 2719-2740.

Penner, J.E., Dong, X., \& Chen, Y. (2004). Observational evidence of a change in radiative forcing due to indirect aerosol effect. Nature, 427, 231-234.

Perez, N., Pey, J., Querol, X., Alastuey, A., Lopez, J.M. \& Viana, M. (2008). Partitioning of major and trace components in $\mathrm{PM}_{10^{-}} \mathrm{PM}_{2.5}-\mathrm{PM}_{1}$ at an urban site in Southtern Europe. Atmospheric Environment, 42, 8, 1677-1691.

Pey, J., Pérez, N., Castillo, S., Viana, M., Moreno, T., Pandolfi, M., López-Sebastián, J.M., Alastuey, A. \& Querol, X. (2009). Geochemistry of regional background aerosols in the Western Mediterranean, Atmospheric research, 94, 3, 422-435.

Pey,J., Alastuey, A., Querol, X., Pérez, N. \& Cusack, M. (2010). Monitoring of sources and atmospheric processes controlling air quality in an urban Mediteranean environment. Atmospheric Environment, 44, 2, 285-299

Pope III, C.A. \& Dockery, D.W. (1999). Epidemiology of particle effects. Air Pollution and Health 31, 673-705.

Pope, C.A., Burnett, R.T., Thun, M.J., Calle, E.E., Krewski, D., Ito, K. \& Thurston, G.D. (2002). Lung cancer, cardiopulmonary mortality, and long-term exposure to fine particulate air pollution. Journal of the American Medical Association, 287, 11321141. 
Putaud, J.P. et al. (2004). A european aerosol phenomenology -2: chemical characteristics of particulate matter at kerbsite, urban, rural and background sites in Europe. Atmospheric Environment 38, 2579-2595.

Putaud et al. (2010). A European aerosol phenomenology-3 : Physical and chemical characteristics of particulate mater from 60 rural, urban and kerbside sites across Europe. Atmospheric Environment, 44, 10, 1308-1320.

Querol, X., Alastuey, A., Viana, M., Rodriguez, M., Artinano, S., Salvador, B., Garciado Santos, P., Fernandez Patier, S., Ruiz, R., de la Rosa, C.R., Sanchez de la Campaa, J., Menendez, A.,M. \& Gil, J.I. (2004). Speciation and origin of PM10 and PM2.5 in Spain. Aerosol Science, 35, 1151-1172.

Ruellan, S., H. \& Cachier (2001). Characterisation of fresh particulate vehicular exhausts near a Paris high flow road. Atmospheric Environment 35, 453-468.

Salma, I., Borsós, T., Weidinger, T., Aalto, P., Hussein, T., Dal Maso, M., \& Kulmala, M. (2011). Production, growth and properties of ultrafine atmospheric aerosol particles in an urban environment, Atmos. Chem. Phys., 11, 1339-1353

Schwarz, J., Chi, X., Maenhaut, W., Civiš, M., Hovorka, J. \& Smolík, J. (2008). Elemental and organic carbon in atmospheric aerosols at downtown and suburban sites in Prague. Atmospheric Research, 90, 2-4, 287-302

Sellegri K., Gourdeau, J., Putaud J.P. \& Despiau, S. (2001). Chemical composition of marine aerosol in a Mediterranean coastal zone during the FETCH experiment, Journal of Geophysical Research, 106, D11, 12023-12037.

Van Dingenen R. et al. (2004). A European aerosol phenomenology-1: physical characteristics of particulate matter at kerbside, urban, rural and background sites in Europe. Atmospheric Environment 38, 2561-2577.

Viana, M., Pérez, C., Querol, X., Alastuey, A., Nickovic, S. \& Baldasano, J.M. (2005). Spatial and temporal variability of PM levels and composition in a complex summer atmospheric scenario in Barcelona (NE Spain). Atmospheric Environment 39, 53435361.

Viana, M., Maenhaut, W., ten Brink, H.M., Chi, X., Weijers, E., Querol, X., Alastuey, A., Mikuska, P., \& Vecera, Z. (2007). Comparative analysis of organic and elemental carbon concentrations in carbonaceous aerosols in three European cities. Atmospheric Environment, 41, 28, 5972-5983.

Viidanoja, J., Sillanpää, M., Laakia, J., Kerminen, V.M., Hillamo, R., Aarnio, P. \& Koskentalo, T. (2002). Organic and black carbon in PM2.5 and PM10: 1 year of data from an urban site in Helsinki, Finland, Atmospheric Environment, 36, 3183-3193.

Wichmann, H.E. \& Peters, A. (2000). Epidemiological evidence of the effects of ultrafine particle exposure. Philosophical Transactions of the Royal Society of Londo,n A358, 2751-2769.

Yttri K. E., Aas, W., Bjerke, A., Cape, J.N., Cavalli, F., Ceburnis, D., Dye, C., Emblico, L., Facchini, M.C., Forster, C., Hanssen, J.E., Hansson, H.C., Jennings, S.C., Maenhaut, W., Putaud, J.P. \& Torseth, K. (2007). Elemental and organic carbon in $\mathrm{PM}_{10}$ : one year measurement campaign within the European Monitoring and Evaluation Programme EMEP. ACP , 7, 22, 5711-5725. 
Yue, D. L., Hu, M., Wu, Z. J., Guo, S., Wen, M. T., Nowak, A., Wehner, B., Wiedensohler, A., Takegawa, N., Kondo, Y., Wang, X. S., Li, Y. P., Zeng, L. M. \& Zhang, Y. H. (2010). Variation of particle Number size distributions and chemical compositions at the urban and downwind regional sites in the Pearl River Delta during summertime pollution episodes. Atmos. Chem. Phys., 10, 9431-9439, doi:10.5194/acp-10-94312010. 


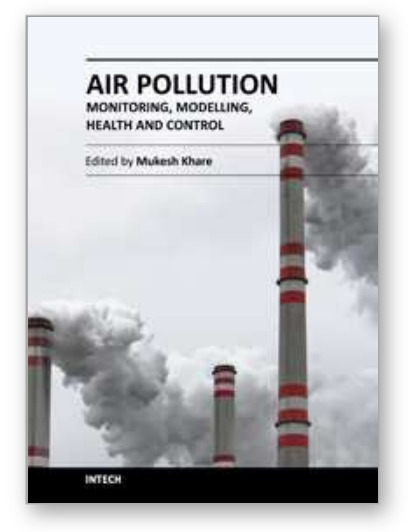

\author{
Air Pollution - Monitoring, Modelling, Health and Control \\ Edited by Dr. Mukesh Khare
}

ISBN 978-953-51-0381-3

Hard cover, 254 pages

Publisher InTech

Published online 21, March, 2012

Published in print edition March, 2012

Air pollution has always been a trans-boundary environmental problem and a matter of global concern for past many years. High concentrations of air pollutants due to numerous anthropogenic activities influence the air quality. There are many books on this subject, but the one in front of you will probably help in filling the gaps existing in the area of air quality monitoring, modelling, exposure, health and control, and can be of great help to graduate students professionals and researchers. The book is divided in two volumes dealing with various monitoring techniques of air pollutants, their predictions and control. It also contains case studies describing the exposure and health implications of air pollutants on living biota in different countries across the globe.

\title{
How to reference
}

In order to correctly reference this scholarly work, feel free to copy and paste the following:

S. Despiau (2012). Physico-Chemical Characterisation of Aerosol Particles at Canopy Level in Urban Zone, Air Pollution - Monitoring, Modelling, Health and Control, Dr. Mukesh Khare (Ed.), ISBN: 978-953-51-0381-3, InTech, Available from: http://www.intechopen.com/books/air-pollution-monitoring-modelling-health-andcontrol/physico-chemical-characterisation-of-aerosol-particles-at-canopy-level-in-urban-zone

\section{INTECH}

open science | open minds

\section{InTech Europe}

University Campus STeP Ri Slavka Krautzeka 83/A 51000 Rijeka, Croatia Phone: +385 (51) 770447

Fax: +385 (51) 686166 www.intechopen.com

\section{InTech China}

Unit 405, Office Block, Hotel Equatorial Shanghai No.65, Yan An Road (West), Shanghai, 200040, China 中国上海市延安西路65号上海国际贵都大饭店办公楼405单元 Phone: +86-21-62489820

Fax: $+86-21-62489821$ 
(C) 2012 The Author(s). Licensee IntechOpen. This is an open access article distributed under the terms of the Creative Commons Attribution 3.0 License, which permits unrestricted use, distribution, and reproduction in any medium, provided the original work is properly cited. 